\title{
Dorota Połowniak-Wawrzonek, Wpływ mediów na współczesna polska frazeologię, Wydawnictwo Uniwersytetu Humanistyczno-Przyrodniczego Jana Kochanowskiego, Kielce 2010, ss. 399
}

Rozprawa habilitacyjna dr Doroty Połowniak-Wawrzonek Wpływ mediów na współczesna polska frazeologię liczy 399 stron druku, składa z pięciu obszernych rozdziałów (s. 17-366) i tzw. obudowy, którą tworzą: wstęp (s. 7-17), zakończenie (s. 367-374), bibliografia (s. 375-386), wykaz źródeł (s. 387-390), wykaz skrótów (s. 391-394) i indeks frazeologizmów (s. 395-399). Wszystkie rozdziały mają ten sam układ wewnętrzny: składają się z małych monografii utrwalających się połączeń słownych, zestawionych nie alfabetycznie, lecz merytorycznie. Taki układ wyraźnie przypomina kompozycyjną zasadę zastosowaną w Przenośniach mowy potocznej Antoniego Krasnowolskiego z początku XX wieku, choć autorka nigdzie o tym nie wspomina. Zestawiony w książce bardzo bogaty i oryginalny materiał ilustracyjny można by ułożyć alfabetycznie, wtedy powstałoby coś na kształt słownika polskich frazeologizmów medialnych. Manewr ten miałby tę zaletę, że w opisie frazeologizmów medialnych pozwoliłby na uniknięcie ,tranzycyjnych” powtórzeń w postaci zapowiedzi analizy poszczególnych związków słownych. Tej uwagi o kompozycji zrębu dzieła nie traktuję jako zarzutu; autorka wybrała własny sposób rejestracji i opisu materiału, co nie rzutuje ujemnie ani na jego interpretację, ani na wnioski z niej wynikające.

Głównym problemem rozważań autorki jest jeden ze sposobów pomnażania współczesnej polskiej frazeologii, wyjaśniony i opracowany kompleksowo. Wpływ mediów na frazeologię przejawia się na dwa sposoby: media są pośrednikiem w zasilaniu zasobu frazeologicznego atrakcyjnymi połączeniami wyrazów przejmowanymi z mowy polityków, mowy bohaterów filmowych, z tekstów piosenek, reklam oraz same wytwarzają wiele zbitek słownych, które utrwalają się w języku niemedialnym. Wraz z końcem XX wieku przestała 
oddziaływać na frazeologię literatura piękna, efektownie zastąpiły ją media. Stosując kryteria powtarzalności i odtwarzalności jako przejawów frazeologizacji określonych połączeń słownych, można - tak jak to czyni autorka monografii - wyodrębnić bogatą warstwę nowej frazeologii. Trzeba mieć jednak na uwadze, że o pozostaniu w języku wielu frazeologizmów zadecyduje upływ czasu. Dziś szansę na to mają przede wszystkim te z nich, które przybierają postać wyrażeń, zwrotów, fraz i porównań, np. szybki Bill, gadające głowy, moherowe berety, wojna na górze, propozycja nie do odrzucenia, puścić kogo w skarpetkach, rżnać głupa, tadować akumulatory, nie ma mocnych, sami swoi, ktoś (coś) jest lekiem na całe zło, jak w czeskim filmie, a bez szans na utrwalenie się są choćby takie, jak: co ty wiesz o zabijaniu, jak dobrze mieć sąsiada, ktoś ma ochotę na chwileczkę zapomnienia, nie chce mi się z tobq gadać, orta cień, lub czasopisma, piękny Marian 'Marian Krzaklewski', maty wielki człowiek, szafa Lesiaka, zielono mi!, żelazny Józef 'Józef Cyrankiewicz' i in. Warstwa ta stała się przedmiotem wszechstronnej analizy, w której bezbłędnie spożytkowano ustalenia płynące nie tylko $z$ teorii frazeologii, lecz także z etymologii, stylistyki, semantyki i słowotwórstwa. Przytoczony w rozprawie materiał ilustracyjny użycia nowych frazeologizmów jest pod każdym względem imponujący, a jego analiza ma wymierną wartość dowodową. W opisie i interpretacji materiału uwzględniła autorka takie mechanizmy frazeologizacyjne, jak zmiana odnośności realnej, przesunięcia semantyczne, wariancja, derywacja frazeologiczna i derywacja odfrazeologiczna. Profesorowie Andrzej M. Lewicki i Anna Tyrpa - recenzenci wydawniczy Wpływu mediów na wspótczesna polska frazeologię - wysoko ocenili rozprawę i jej walory poznawcze. W pełni podzielam ich sądy, choć mam nieco inne spojrzenie na frazeologię niż oni (a za nimi autorka rozprawy), co nie znaczy, że nie honoruję upowszechnionego w polskiej frazeologii poglądu prof. Lewickiego o wieloaspektowym charakterze frazeologii jako nauki doceniającej wszelkie nowe, fortunnie zrealizowane pomysły badawcze, przynoszące ciekawe i trwałe wyniki i ustalenia, a takie właśnie daje gruntowna analiza materiału przedstawiona w recenzowanej rozprawie dr Połowniak-Wawrzonek. Świadczy o tym sama prezentacja wniosków zawarta w zwięzłym podsumowaniu monografii. Oto wybrane z nich: 1) oddziaływanie mediów na współczesną polską frazeologię trzeba wiązać z przejawami tendencji do upotocznienia języka mediów, która zaznaczyła się wyraźnie po ostatniej zmianie ustrojowej, 2) w połączeniach wyrazowych utrwalonych wskutek oddziaływania mediów ujawnia się swoisty antropocentryzm, doświadczenia typowe dla polskiej społeczności, 3) stałe połączenia słowne utrwalone wskutek oddziaływania mediów funkcjonują zarówno w postaci kanonicznej, jak i zmodyfikowanej, przy czym modyfikacje zawsze wzmacniają inwariant danej jednostki, 4) w od- 
działywaniu tekstów piosenek wyróżnia się grupa połączeń wywodzących się z ambitnych utworów poetyckich, natomiast wśród związków utrwalanych dzięki wpływowi filmów, seriali telewizyjnych - połączenia będące pierwotnie tytułami tych komunikatów medialnych albo wypowiedziami ich bohaterów, 5) analiza jednostek wywodzących się z reklamy ujawniła, że najczęściej pochodzą one z niezbyt oryginalnych sloganów, 6) w wyniku oddziaływania mediów do polszczyzny ogólnej przenikają nie tylko połączenia z potocznego rejestru stylu niskiego, lecz także - związki wyrazowe z określonych socjolektów, 7) niektóre z nowych połączeń wyrazowych mają charakter europeizmów i internacjonalizmów. Wnioski te nie nasuwają uwag krytycznych, należy je zatem w pełni zaakceptować.

Monografia Doroty Połowniak-Wawrzonek Wpływ mediów na wspótczesna polska frazeologię wydatnie wzbogaca dotychczasowe opracowania zasobu frazeologicznego dzisiejszej polszczyzny.

Stanistaw Bąba 